\title{
First record of Microlynchia pusilla (Diptera: Hippoboscidae) in Northeastern Brazil
}

\author{
Primeiro registro de Microlynchia pusilla (Diptera: Hippoboscidae) no Nordeste do Brasil \\ Honara Morgana da Silva ${ }^{1 *}$; Mauro Pichorim ${ }^{1}$ \\ ${ }^{1}$ Laboratório de Ornitologia, Departamento de Botânica, Ecologia e Zoologia, \\ Universidade Federal do Rio Grande do Norte - UFRN, Natal, RN, Brasil \\ Received September 10, 2012 \\ Accepted February 21, 2013

\begin{abstract}
The present paper reports the occurrence of Microlynchia pusilla in the state of Rio Grande do Norte (RN) on Leptotila verreauxi approximans from a deciduous forest fragment located in the municipality of Macaíba. A specimen of L. v. approximans was collected in June 2012, wrapped in paper towels and kept under refrigeration in a plastic bag for later analysis of parasite fauna, taxidermy, and eventual storage in the Ornithological Collection of the Federal University of Rio Grande do Norte (UFRN). During the search for ectoparasites, a specimen of M. pusilla was found among feathers of the ventral region; it was collected and stored in the Entomological Collection 'Adalberto Antônio Varela-Freire' of the same university. This report extends the knowledge about geographical distribution and confirms the association of $M$. pusilla with hosts Columbiformes, contributing to the knowledge of the family Hippoboscidae in the country.
\end{abstract}

Keywords: Ectoparasites, Rio Grande do Norte, louse flies, Leptotila verreauxi approximans.

\section{Resumo}

Este trabalho registra a ocorrência de Microlynchia pusilla no estado do Rio Grande do Norte em Leptotila verreauxi approximans oriunda de um fragmento de floresta estacional decidual localizado no município de Macaíba. Um espécime de L. v. approximans foi coletado em junho de 2012, envolvido em papel toalha e conservado sob refrigeração em saco plástico para posterior análise da fauna parasitária, taxidermia e depósito na Coleção Ornitológica da Universidade Federal do Rio Grande do Norte (UFRN). Durante a busca por ectoparasitos foi encontrado um espécime de $M$. pusilla nas penas da região ventral, o qual foi coletado e depositado na Coleção Entomológica Adalberto Antônio Varela-Freire da mesma universidade. Este relato amplia o conhecimento sobre a distribuição geográfica de $M$. pusilla e confirma sua associação com hospedeiros Columbiformes, contribuindo para o conhecimento da família Hippoboscidae no país.

Palavras-chave: Ectoparasitos, Rio Grande do Norte, hipoboscídeos, Leptotila verreauxi approximans.

Hippoboscidae are hematophagous flies, ectoparasites of birds and mammals (WOOD, 2009). They present wide geographical distribution, being more diverse in the tropics and subtropics (SCUDDER; CANNINGS, 2006), and comprise about 200 described species, distributed in 21 genera and three subfamilies (GREDILHA et al., 2008). In Brazil, studies on Hippoboscidae began when Lutz et al. (1915) catalogued and provided an identification key to 15 species found until then, followed by Bequaert (1954, 1955, 1957) and Maa (1969), who added information about the family within the national territory. Currently, there are 26 known species parasitizing birds (ARZUA; VALIM, 2010); however, there are still significant gaps in geography and host association to be filled in the country

\footnotetext{
${ }^{*}$ Corresponding author: Honara Morgana da Silva

Programa de Pós-graduação em Ecologia, Universidade Federal do Rio Grande do

Norte, Natal, RN 59072-970, Brasil

e-mail: honaramorgana@gmail.com
}

(GRACIOLLI; CARVALHO, 2003). The genus Microlynchia (Lutz, Neiva \& Costa-Lima, 1915) comprises four species, M. galapagoensis (Bequaert, 1955) is endemic in the Galapagos Islands and the other species are restricted to the Americas (MAA, 1969). Microlynchia pusilla (Speiser, 1902) is the species with the widest distribution, reaching the U.S., Mexico, Costa Rica, the Antilles, Colombia, Venezuela, Brazil, Peru, Paraguay, and Chile (MAA, 1969). It has low degree of host specificity, since it has been recorded parasitizing about ten families of birds: Accipitridae, Caprimulgidae, Columbidae, Cuculidae, Fringillidae, Icteridae, Momotidae, Muscicapidae, and Tinamidae families (MAA, 1969). Maa (1969) mentions the association of M. pusilla with the genus Leptotila (Swainson, 1837), but does not report any specific relation. Nevertheless, Leptotila verreaxuxi decipiens (Salvadori, 1871) was recorded as host of $M$. pusilla in Peru (BEQUAERT, 1955). In Brazil, this fly was recorded in Mato Grosso, Rio de Janeiro, Minas Gerais, and Espírito Santo 
states parasitizing Columbiformes (LUTZ et al., 1915; MAA, 1969; ARZUA; VALIM, 2010). Among these, Lutz et al. (1915) reports having found it on doves and pigeons, but the species were not named. According to Bequaert (1955), M. pusilla was found on Columbina sp. and Columba livia (Gmelin, 1789) in Rio de Janeiro, and on Crypturellus sp. in Mato Grosso; the author mentions Columbina talpacoti (Temminck, 1811) and Columbina passerina (Linnaeus, 1758) as its hosts. In 2004, Valim et al. recorded the species on Columbina talpacoti in Rio de Janeiro, corroborating those findings. Therefore, it may be concluded that in Brazil, so far, $M$. pusilla has been found parasitizing birds of the order Columbiformes exclusively. During an ample survey of birds ectoparasites in northeastern Brazil developed by the Laboratory of Ornithology of UFRN, a specimen of Leptotila verreauxi approximans (Cory, 1917) (adult female) was collected on June 10, 2012 in the woods surrounding the Agricultural School of Jundiaí, municipality of Macaíba, RN (forest fragment of about 270 ha, center coordinates $5^{\circ} 53^{\prime} \mathrm{S}$ and $35^{\circ} 23^{\prime} \mathrm{W}$, about $40 \mathrm{~m}$ above sea level). The bird was captured with Ecotone mist nets $(12 \times 3 \mathrm{~m}$, mesh $19 \mathrm{~mm})$, killed by thoracic compression, wrapped in paper towels and kept refrigerated in a plastic bag for later analysis of parasite fauna, taxidermy, and held in the Ornithological Collection of the Federal University of Rio Grande do Norte (COUFRN-654). The collection was authorized by the Brazilian Institute for the Environment and Renewable Natural Resources (IBAMA), under permanent license for collection of zoological material number 19849-1 (authentication code: 28111788; issuance date: 27/04/2009). Before taxidermy, a careful examination of the bird was performed in search of ectoparasites. A female specimen of louse fly was found in the plumage of the chest and belly, collected and preserved in alcohol 70\%. The Hippoboscidae was identified in stereomicroscope with the aid of the taxonomic keys by Bequaert $(1933,1955)$ and Wood (2009), and held in the Entomological Collection 'Adalberto Antônio Varela-Freire' at UFRN (MAN-0590). It is important to point out that even though only a single specimen was found, this is the first record of Microlynchia pusilla in northeastern Brazil. Furthermore, although this species commonly infests birds of the order Columbiformes, there is no record of the specific association with Leptotila verreauxi in the country. Such reports contribute to the knowledge of geography and association of parasites with their host species, aiding studies of ecological interaction and coevolution.

\section{Acknowledgments}

To the staff of the Laboratory of Ornithology of UFRN, especially Matheus Meira, Tonny Marques, Guilherme Toledo, Phoeve Macário, Priscila Sabino, Victor Fernandes, Thanyria Câmara, Damiāo Valdenor de Oliveira, Elaine Bandeira, and Ismael
Queiroz for their essential support in field work during collection. We thank Professor Dr. Gustavo Graciolli for the information about the distribution of the Hippoboscidae family in Brazil.

\section{References}

Arzua M, Valim MP. Bases para o estudo qualitativo e quantitativo de ectoparasitos em aves. In: Matter SV, Piacentini VQ, Straube FC, Cândido JF Jr, Accordi IA. Ornitologia e conservação: ciência aplicada, técnicas de pesquisa e levantamento. Rio de Janeiro: Technical Books; 2010. p. 347-366.

Bequaert JC. Notes on Hippoboscidae. Psyche 1933; 40(2): 68-82. http:// dx.doi.org/10.1155/1933/94603

Bequaert JC. The hippoboscidae or louse-flies (Diptera) of mammals and birds Part II. Taxonomy, evolution and revision of American genera and species. Entomol Am News Ser 1954; 34: 1-232.

Bequaert JC. The Hippoboscidae or louse-flies (Diptera) of mammals and birds. Part II. Taxonomy, Evolution and Revision of American Genera and Species. Entomol Am 1955; 35: 233-416.

Bequaert JC. The hippoboscidae or louse-flies (Diptera) of mammals and birds Part II. Taxonomy, evolution and revision of American genera and species. Entomol Am News Ser 1957; 35: 417-610.

Graciolli G, Carvalho CJB. Hippoboscidae (Diptera, Hippoboscoidea) no estado do Paraná, Brasil: chaves de identificação, hospedeiros e distribuição geográfica. Rev Bras Zool 2003; 20(4): 667-674. http:// dx.doi.org/10.1590/S010181752003000400019

Gredilha R, Balthazar DA, Spadetti AL, Fedullo LPL, Mello RP. Pseudolynchia canariensis (Diptera: Hippoboscidae) em Buteogallus aequinoctialis (Ciconiiformes: Accipitridae) no estado do Rio de Janeiro, Brasil. Rev Bras Parasitol Vet 2008; 17(2): 110-112. PMid:18823580. http://dx.doi.org/10.1590/S1984-29612008000200009

Maa TC. A revised checklist and concise host index of Hippoboscidae (Diptera). Pac Insects Monogr 1969; 20: 261-299.

Lutz A, Neiva A, Costa-Lima A. Sobre "Pupipara" ou "Hippoboscidae" de aves brasileiras. Mem Inst Oswaldo Cruz 1915; 7(2): 173-199. http:// dx.doi.org/10.1590/S0074-02761915000200003

Scudder GGE, Cannings RA. The diptera families of British Columbia. 2006. Available from: http://www.for.gov.bc.ca/hfd/library/ fia/2006/fsp_y062001b.pdf.

Valim MP, Serra-Freire RT, Fonseca MA, Serra-Freire NM. Níveis de enzootia por ectoparasitos em amostras de rolinha [Columbina talpacoti (Temminck, 1810)] no Rio de Janeiro, Brasil. Entomol vectores 2004; 11(4): 589-598.

Wood DM. Hippoboscidae (Louse-Flies). In: Brown BV, Borkent A, Cumming JM, Wood DM, Woodley NE, Zumbado MA. Manual of Central American Diptera. Ottawa: NRC Research Press; 2009. p. 1241-1248. 